\title{
THE UNIVERSITY IN THE EPOCH OF DIGITAL REASON: FAST KNOWLEDGE IN THE CIRCUITS OF CYBERNETIC CAPITALISM
}

\author{
MICHAEL A. PETERS \\ mpeters@waikato.ac.nz \\ University of Waikato; \\ University of Illinois at Urbana-Champaign
}

\begin{abstract}
This article examines the university institutional in relation to the notion of time by postulating the concept of "the epoch of digital reason." Within this epoch the university exhibits "fast knowledge" flows of knowledge in the circuits of "cybernetic capitalism." The paper introduces the university on speed through the work of Paul Virilio and then in the next sections examines "the epoch of digital reason," fast knowledge and fast capitalism and "the cybernetic hypothesis" including a conception of the university and "speed politics" within cybernetic capitalism.
\end{abstract}

Keywords: university; speed politics; digital reason; cybernetic capitalism;

fast knowledge; financialization

How to cite: Peters, Michael A. (2015), "The University in the Epoch of Digital Reason:

Fast Knowledge in the Circuits of Cybernetic Capitalism," Analysis and Metaphysics 14:

$38-58$.

Received 9 January $2015 \cdot$ Received in revised form 24 September 2015

Accepted 24 September $2015 \cdot$ Available online 1 October 2015

'Time is money' . . 'speed is power': We have moved from the stage of the acceleration of History to that of the acceleration of the Real. This is what 'the progress' is: a consensual sacrifice. Paul Virilio (2008), "Paul Virilio on the Crisis," in Radical Perspectives on the Crisis, https://sites.google.com/site/radical perspectivesonthecrisis/news/paul-virilio-on-the-crisis 


\section{Introduction: The University on Speed}

The French urbanist and philosopher Paul Virilio is one of the principal theorists of speed. After many years pursuing the relationship between concepts of velocity and the paradox of being in a virtual world - of being somewhere and nowhere at the same time - Virilio explains how real time has supplanted real space such that "A synchronization has taken place of customs, habits, mores, ways to react to things, and also, of emotions," exemplified in the hysteria that followed the global financial crisis. He maintains: "Since speed earns money, the financial sphere has attempted to enforce the value of time above the value of space and while this has led to massive profits for the few and increasing inequalities, to truly understand the phenomenon of an economy of speed, the left has to jettison its old framework that insists capitalism is dead, and all we need is more social justice. This is a false deduction that proceeds from adopting the same old materialist analysis."

Whether one accepts Virilio's analysis or his predictions, it is clear that speed and velocity are two of the main aspects of a new finance capitalism that operates at the speed of light based on sophisticated "buy" and "sell" algorithms. Already researchers have demonstrated that data transfer using a single laser can send 26 terabits per second down an optical fibre and there are comparable reports that lasers will make financial "high-frequency" trading even faster. ${ }^{2}$

The game has changed permanently. Now universities are "engines of innovation" for "fast capitalism" dealing in "fast knowledge," "fast publishing" and "fast teaching" (e.g. massive open online courses (MOOCs)) where "knowledge" (confused with information) is seen as having a rapidly decreasing shelf-life. We have passed the bedding-down stage of neoliberal universities that occurred with the transformation of the public sphere during the Reagan-Thatcher decades of the 1980s and 1990s. We have passed the stage of the adoption of principles of New Public Management and the emulation of private sector management styles to enter an era of universities in the service of finance capitalism where universities, increasingly reliant on student fees (especially international students) and independent research funds, serviced by high-speed networks and MOOCs, operate as a part of global finance culture.

Increasingly universities are instrumental in generating and managing a burgeoning student debt. ${ }^{3}$ They have become loan institutions that gamble with endowments and make investments in futures markets. They prioritize research that generates income, develop global partnerships with like institutions and consortia to act as powerful actors in the global higher education market, often overly concerned with branding, institutional image, positioning and global marketing. In this new context the university is increasingly 
preoccupied with finance, with financial global partners, imbued with a finance culture that permeates the institution substituting at every turn for academic leadership and academic culture, downplaying the very sources of self-criticism that used to characterize the university and playing up the financial and reputational stakes.

One might also add that at the very heart of a permanent change of regime is the relationship between global capitalism and the new information and communication technologies, a relationship that has developed quickly in the postwar context to create what I call "cybernetic capitalism," a term I introduce to emphasis the new circuits and forms of global capital and new mode of capital accumulation. At the same time, the social and communicative acceleration that results from this relationship at the heart of cybernetic capitalism can be understood in philosophical terms that change the basis for temporality, for subjectivity and being: being a student, being a professor, being a university.

In the first part of this paper I introduce the notion of "digital reason" and describe main features of the university in the epoch of digital reason as a philosophical basis for understanding so-called "fast capitalism" and "fast knowledge" and various theorizations of cybernetics in relation to the university.

\section{The Epoch of Digital Reason}

Global finance capitalism (and "financialization") is but one prominent and rapidly growing aspect of "cybernetic capitalism." Western modernity and the developing global systems spawned by western (neo)liberal capitalism exhibit long-term tendencies of an increasing abstraction that can be described in terms of long-term modernization processes, including the "formalization," "mathematicization," "aestheticization" and "biologization" of everyday life (Peters, Britez and Bulut, 2009; Peters, 2011). These cybernetic processes are characteristic of otherwise seemingly disparate pursuits in the arts and humanities as much as science and technology and have been driven in large measure through the development of logic and mathematics, especially in the world architecture of emerging global digital systems. In this respect we can talk of the emergence of digital reason and of the university in the epoch of digital reason. By this description I mean principally a set of developments in foundations of mathematics and the algebra of logic that predate the founding of cybernetics as a discipline, with the 1946 and 1953 conferences sponsored by the Josiah Macy Jr. Foundation in New York City on the subject of "Circular Causal and Feedback Mechanisms in Biological and Social Systems" (Umpleby, 2005). The prehistory of cybernetics that results in the problematic history of the development of digital logic, including Boolean 
algebra, gates that process logic signals, switching theory, flip-flops and memory elements that store logic signals and in general the representation of binary information in physical systems. In this tangled genealogy George Boole (1847) wrote The Mathematical Analysis of Logic that provided the calculus for a two-valued logic, applying algebra to logic, representing true or false within assertion logic that is the basis for all modern programming languages and digital electronics. Claude Shannon discovered that the rule of Boolean algebra could be applied to switching circuits and introduced switching algebra in order to design circuits of logic gates. (The algebra of 0 and 1 was applied to electrical hardware comprising logic gates to form a circuit diagram. $)^{4}$

Digital reason is a wider and a more philosophical notion than digital logic, named here in the tradition of Kant and Foucault. It governs the historical emergence of a techno-epistemological epoch that is so recent but indicates a deep transformation of economy, society and the university. Its concepts are the concepts of speed and velocity - involving limits of the physics of light - as well as system, feedback and control. Much of this rapid transformation of digital logic and the properties of systems can be captured in the notion of "algorithmic capitalism" (Peters, 2012a; 2012c; 2013) as an aspect of informationalism (informational capitalism) or "cybernetic capitalism," a term that recognizes more precisely the cybernetic system similarities among various sectors of the post-industrial capitalist economy in its third phase of development - from mercantilism to industrialism and finally to cybernetics - linking the growth of the multinational info-utilities (e.g. Google, Microsoft, Amazon) and their spectacular growth in the last twenty years, with developments in biocapitalism (the informatization of biology and biologization of information), and fundamental changes taking place in the nature of the market with algorithmic trading and the development of socalled "financialization." This paper examines these trends and makes an assessment of the long-term effects of them on universities.

\section{Fast Capitalism, Fast Knowledge}

Filip Vostal (2013: 96) in his paper "Thematizing Speed: Between Critical Theory and Cultural Analysis" notes (following Tomlinson, 2007) that the issue of social speed and time has been treated as a subsidiary theme by the founders of modern sociology and also by those like Bauman and Castells who theorize globalization. He claims "Only recently have some social theorists started to develop systematic theories and analyses that address speed as a self-standing social phenomenon" (Vostal, 2013: 97) and mentions in this regard "Hartmut Rosa's critical theory of acceleration and John Tomlinson's 
investigation of modern cultures of speed" (ibid.). He goes on to offer the following description under the heading "Critique of the ever-faster lifeworld:"

There are several seminal book-length accounts (Agger, 1989, 2004; Hassan, 2003, 2009, 2012) that develop a critique of speed. This body of literature distils, and in a sense systematizes, speed as a modern and above all capitalist imperative with a plethora of negative consequences for the environment, health, self-determination, individual autonomy, democracy, intellectual pursuits and social reproduction. . . . Essentially, the authors . . . the Frankfurt School tradition by identifying speed as the central feature in the capitalist production process, which obstructs 'mechanisms of reaching understanding' and thereby 'colonizes the lifeworld' and by highlighting the capitalist reification of time as the pivotal cause behind 'the eclipse of reason.'

He makes the point that Agger and Hassan focus on the mode of capitalist production that they take as synonymous with modernity or with providing the motor for acceleration especially through the labor process. By contrast to this account he profiles Rosa's differentiation between (1) technological acceleration; (2) acceleration of social change; and (3) acceleration of the pace of life, and he also profiles Tomlinson's "cultural modalities of speed." Klinke (2012) also provides us with a reading of existing chronopolitics staring with Virilio's analysis of speed, acceleration and warfare (rather than capital accumulation) and the postcolonial geopolitical interpretation of political time evident in the work of scholars like Johannes Fabian and John Agnew.

In this paper I develop an account of cybernetic capitalism that provides an analytical understanding in terms of digital reason of the differences between industrial and cybernetic modes of production in relation to the university. It is an analysis that goes beyond acceleration to understand why cybernetic systems are temporally grounded in digital logic and its application to electrical engineering (so-called switching theory), which has become the engine of new varieties of cybernetic capitalism where the logic of capital accumulation is facilitated by cybernetic systems. By comparison with the industrial mode of production, cybernetics serves as a new logic for accelerated accumulation strategies harnessing the new media technologies to exploit truly massive global markets. Tim Luke (2005) provides us with an account of fast capitalism:

Fast capitalism is a 24/7 reality. Its statics and dynamics require social theorists to delve into dromology, or disciplined discursive deliberations over the new modes of power and knowledge generated by speed itself. As one gains awareness of how speed shapes social practices, it is clear that social theory must consider the power of kinetics as a fundamental force in everyday life. Whether it is defined as 'dromocracy' (Virilio 1986), 'time-space 
compression' (Harvey 1989) or 'fast capitalism' (Agger 1989), today's temporal terrains, as Virilio asserts, are embedded in 'chrono-politics' through which 'speed rules' over every aspect of life now being reformatted by 'the dromocratic revolution' (Virilio and Lotringer 1983: 43-51). These effects are both global and local in their scope and impact, although their impact on culture, economy, and society is not fully understood. www.uta.edu/huma/ agger/fastcapitalism/1_1/luke.html

As Robert Babe (2006) notes "Fast capitalism depends . . . on the volume, speed, and territorial expanse of digitized communication networks, on reduced time for product cycles, on accelerating speeds of style and model changes, and perhaps most importantly on imagery embedding mythic meanings onto the banality of mass produced consumer items." As such, post-structuralist thought "is the ontology best supporting and depicting today's fast capitalism."

It was this kind of characterization that motivated Agger and Luke to cofound the journal Fast Capitalism in 2005, now celebrating its tenth issue. ${ }^{5}$ In the Editor's Introduction Agger and Luke (2013a) write about the internet as the new public sphere and lay out their rationale:

People use the Internet as a public sphere in which they express and enlighten themselves and organize others ... We are convinced that the best way to study an accelerated media culture and its various political economies and existential meanings is dialectically, with nuance, avoiding sheer condemnation and ebullient celebration. We seek to shape these new technologies and social structures in democratic ways. Www.fastcapitalism.com

In the recent issue Agger and Luke (2013b) reflect on the possibility of critical social theory in the digital age suggesting:

Older existing print journals had not yet fully made their ways into the digital domain, and maybe some of them never would. What could a 'born digital' journal do differently, how might it create new scholarly networks, who would join its experiments from across the academy, around the world, and alongside the established media ecologies of print journals? Running with this sense of curiosity, and pushing ahead with a willingness to give it a try. Fast Capitalism journal posted its 1.1 issue in 2005.

\section{The Theatre of Fast Knowledge}

While I did not contribute to the journal I did write a piece with Tina Besley entitled "The Theatre of Fast Knowledge: Performative Epistemologies in Higher Education" (Besley and Peters, 2006) which was an attempt to use 
the concept and theory of fast capitalism to understand and theorize the concept of "fast knowledge" and its consequences for the university. ${ }^{6} \mathrm{We}$ followed the analysis of George Ritzer (1993) in The McDonaldization of Society drawing on the analogy between fast food and fast knowledge. McDonaldization is a reconceptualization of rationalization (after Weber) through the concept of scientific management that results in the homogenization of cultures. The four principles of this process are efficiency, calculability, predictability and control through technology. Using these same principles we applied the model to managing fast knowledge performance that we christened "performative epistemologies" drawing on Lyotard and Foucault. In terms of my more recent thinking "fast knowledge" and speed needs to be understood within the context of cybernetics and cybernetic capitalism no longer tied to linear production models or industrial assemble lines and Tayloristic management regimes.

"Fast knowledge" is part of fast capitalism and serves to highlight an emergent new generic form of capitalism based increasingly on forms of symbolic capital associated with the rise of global finance and with new information and communication technologies. "Knowledge capitalism" conveys the digitalization of knowledge production processes and the way in which all phases of knowledge production - its creation or generation, its storage and retrieval, its formal and informal acquisition and transmission, and its distribution or circulation - have been speeded up, with significant consequences not only for knowledge production but also, more generally, for learning, education and culture.

Speed is of the essence; it defines contemporary capitalism as - "fast" capitalism. As a single principle, speed annihilates distance, increasing access to global markets and promoting the mobility of factors of production. Speed defines the essence of finance and information capitalism. The mobility of capital has greatly increased private capital flows in the symbolic form of information that can be speedily transferred in deregulated 24-hour virtual finance markets, allowing international currency speculation and increased geographical spread of foreign direct investment. In the information economy the effect of location is diminished as virtual marketplaces and virtual organizations offer benefits of speed and agility, of round-the-clock operation, and of global reach. Knowledge and information "leak" to where demand is highest and the barriers are lowest and, thus, laws and taxes are difficult to apply on solely a national basis. The new information and communications technologies have accentuated and augmented aspects of the traditional industrial economy, making even more efficient international transactions and promoting flows of capital, goods, labor and services at the speeds of sound and light. 
This has led to the unparalleled growth of e-commerce and e-business, that is, of electronically mediated business transactions, to create and transform relationships for value creation among organizations and between organizations and individuals. There has been a growing convergence of specific technologies into new integrated systems. The radical and globalized concordance of image, text and sound has created new IT, media, telecommunications and information $=$ knowledge infrastructures, and a global media network reflecting the emergence of a Euro-American dominated global consumer culture with the rise of multinational edutainment conglomerates in music, film and TV. The impact of the new digital technologies permitted liberalization of world capital markets and simultaneously enabled high-tech internet and telecommunications companies to rapidly develop and to make massive gains. The dynamic relationship between capital markets and digital technologies temporarily sustained a financial ecosystem that seemed to call into question the rules of the old game, creating a US innovation system based on large-scale venture capital investment. These developments have led some economists to emphasize the growing importance of an international knowledge system as a basis for a source of labor value and productivity, research and technological innovation.

"Fast knowledge," then, is a central element in knowledge capitalism both as content and as technology, refining the very system that is responsible for its ever-increasing "fast" circulation. Fast knowledge is an inextricable part of finance capitalism and through the model of the copy (copyright, patent and trademark) is controlled by the emerging structures of international property rights regimes, such as GATS (General Agreement on Trade in Services) and TRIPS (Agreement on Trade-Related Aspects of Intellectual Property Rights), which include educational services. Fast knowledge also increasingly defines aspects of the international knowledge system, determining the speed and efficiency of knowledge creation, transmission and distribution (Besley and Peters, 2006).

\section{"The Cybernetic Hypothesis"}

Modern cybernetics began with Norbert Weiner who defined the field with his 1948 book Cybernetics: Or Control and Communication in the Animal and the Machine where he developed the science of information feedback systems, linking control and communication in an understanding of the computer as "ideal central nervous system to an apparatus for automatic control" (Wiener, 1948: 36) and, therefore, referring to the automatic control of animal and machine. The prehistory of the term can be traced back at least to Plato where kybernetes meaning "steersman" or "governor" (from the Latin gubernator) - the same root as government - was used to refer to governing 
of the city-state as an art, based on the metaphor of the art of navigation or steering a ship. Thus, from the beginning, the term was associated with politics and the art of government as well as with communication and organization. $^{7}$

"Governing" as a major root meaning has been picked up in all major definitions including A. M. Ampere, the French scientist, who used it to refer to the science of government, W. Ross Ashby who talked of the "art of steermanship" and Stafford Beer who talked of the science of effective organization. Other modern pioneers in the field tended to emphasize a more technical aspect of the study of systems: "systems open to energy but closed to information" (Ashby); "problems of control, recursiveness, and information" (Gregory Bateson); "feedback as purposeful behavior in man-machines and living organisms" (Ludwig von Bertalanffy); "the deep nature of control" (Beer); "relationship between endogenous goals and the external environment" (Peter Corning); "circularity" (Heinz von Förster); "the theory of interconnectedness of possible dynamic self-regulated systems" (G. Klaus); "the art and science of human understanding" (Umberto Maturana); "the study of justified intervention" (James Wilk).

Cybernetics is also broadly related to systems philosophy and theory and as Charles François (1999: 203) notes both function as "a metalanguage of concepts and models for transdisciplinarian use, still now evolving and far from being stabilized." François (1999) provides a detailed history of systemics and cybernetics in terms of a series historical stages: First, Precursors (before 1948) - the "Prehistory of Systemic-Cybernetic Language" - going back to the Greeks and to Descartes in the modern world and ranging across the disciplines with important work in philosophy, mathematics, biology, psychology, linguistics, physiology, chemistry and so on (Hartmann, Leibnitz, Bernard, Ampère, Poincaré, Konig, Whitehead, Saussure, Christaller, Losch, Xenopol, Bertalanffy, Prigogine). Second, "From Precursors to Pioneers (1948-1960)" beginning with Weiner who aimed to address the problem of prediction and control and the importance of feedback for corrective steering, and mentioning Shannon and Weaver's (1949) Mathematical Theory of Communication, von Bertalanffy's 1950 paper "An Outline of General System Theory," Kenneth Boulding's (1953) Spaceship Earth, von Neumann's theory of automata, von Förster's biological computer and his collaborators like Ashby (1956), Pask (1975) and Maturana who pursued questions in human learning, autopoiesis and cognition. François (1999) rightly devotes space to Prigogine (1955) on systemic and his escape from assumptions of thermodynamic models toward understanding dissipative structures in complex systems. Third, "Innovators (After 1960)" beginning with Simon's (1962) discussion of complexity, Miller's (1978) work on living systems, Maturana's work on autopoiesis, i.e. self-production, Mandelbrot's (1977) 
work on fractal forms, Zadeh's (1965) work on fuzzy sets and fuzzy logic, Thom's work on the theory of catastrophes and the development of chaos theory. As François (1999: 214) writes:

Chaos theory as the study of the irregular, unpredictable behavior of deterministic non-linear systems is one of the most recent and important innovations in systemics. Complex systems are by nature non-linear, and accordingly they cannot be perfectly reduced to linear simplifications.

As Teeple (1995: 7) remarks, new forms of global capitalism "can be defined as the arrival of 'self-generating capital' at the global level: that is, capital as capital, capital in the form of the transnational corporation, increasingly free of national loyalties, controls, and interests." The "financialization of capitalism" then is a process that seems to have accompanied neoliberalism and globalization, representing a shift from production to financial services, proliferation of monopolistic multinational corporations and the financialization of the capital accumulation process.

Various theoretical positions can be entertained here and perhaps the most trenchant critique comes from Tiqqun's (2001) "The Cybernetic Hypothesis" which suggests that cybernetics is a new technology of government,

an autonomous world of apparatuses so blended with the capitalist project that it has become a political project, a gigantic 'abstract machine' made of binary machines run by the Empire, a new form of political sovereignty, which must be called an abstract machine that has made itself into a global war machine.

The manifesto continues:

The Cybernetic Hypothesis is thus a political hypothesis, a new fable that after the Second World War has definitively supplanted the liberal hypothesis. Contrary to the latter, it proposes to conceive biological, physical, and social behaviors as something integrally programmed and re-programmable. More precisely, it conceives of each individual behavior as something 'piloted,' in the last analysis, by the need for the survival of a 'system' that makes it possible, and which it must contribute to.

Tiqqun traces cybernetics as the theoretical and technological outcome and continuation of a state of war based on feedback and control. The post-war information and communication theory together with computer software and hardware emerges from this Cold War background and conditions a cybernetic capitalism where "the social self-regulation process came to be based on the valorization of information." 


\section{Cybernetic Capitalism, the University and Speed Politics}

Each kind of society corresponds to a particular kind of machine with simple mechanical machines corresponding to sovereign societies, thermodynamic machines to disciplinary societies, cybernetic machines and computers to control societies. But the machines don't explain anything, you have to analyze the collective apparatuses of which the machines are just one component.

Gilles Deleuze (1995), "Control and Becoming," in Negotiations 1972-1990. New York: Columbia University Press

The web creates new challenges for information retrieval. The amount of information on the web is growing rapidly, as well as the number of new users inexperienced in the art of web research... Human maintained lists cover popular topics effectively but are subjective, expensive to build and maintain, slow to improve, and cannot cover all esoteric topics. Automated search engines that rely on keyword matching usually return too many low quality matches ... We have built a large-scale search engine which addresses many of the problems of existing systems. It makes especially heavy use of the additional structure present in hypertext to provide much higher quality search results. We chose our system name, Google, because it is a common spelling of googol, or 10100 and fits well with our goal of building very large-scale search engines.

Sergey Brin and Lawrence Page (no date), "The Anatomy of a Large-Scale Hypertextual Web Search Engine," http://infolab.stanford.edu/ backrub/google.html

Contemporary capitalist system is post-industrial where the service sector and information technology and telecommunications companies (ICTs) acquire key role and the working class falls below 20 percent in advanced capitalist economies. The 1980s and 1990s witnessed the rise of big IT corporations such as Microsoft, IBM and Apple, along with the growth of computer hardware, computer software, electronics, communications and mobile telephony as growing economic sectors. Yearly revenues of ICT companies are second only to oil and gas (as a group) with Apple ranking eighteenth (\$170 bn), Verizon forty-fifth ( $\$ 115 \mathrm{bn})$, Hewlett-Packard forty-ninth (\$112 bn), IBM fifty-sixth ( $\$ 104$ bn), with Microsoft ( $\$ 77$ bn), Google ( $\$ 59$ bn), Dell ( $\$ 56.9$ bn), Amazon.com ( $\$ 74.5$ bn), Intel ( $\$ 52.7$ bn), Cisco ( $\$ 43.2$ bn) eBay ( $\$ 16$ bn) and Facebook ( $\$ 7.8 \mathrm{bn}) .{ }^{9}$ By far the largest category is oil and gas (with the one exception of Wal-Mart), which poses the question of the relationship of the university to the energy sector and to industrialism per se with an accent on related subjects like geology, engineering and chemistry. The industrial university relies on the division of labor as Kant (1798/1979) points out in The Conflict of the Faculties, and is regulated by the industrial cycle of time, by commodity cycles driven by price and sales and business and industry cycles determined by product development and techniques of mass production and assembly lines.

The era of digital capitalism, computer science, information and communication technologies and new satellite technologies, beginning in the 1980s, completely transforms the knowledge environment and information infra- 
structure in a neoliberal era that also encourages business studies and a closer relationship to finance culture. Higher education becomes a crucial sector of the information industry where various kinds of performative power intersect directly with new communication and information technologies, especially when framed by the policy template of the knowledge economy. In the knowledge economy the cultural and the symbolic are paramount and the sign economy no longer based on raw materials centers on transformation of ideas and symbolic resources by means of intellectual, human and social capital. In this environment, increasingly the three spheres of the economic, technical and cultural are brought into a close alignment as performative power combines the rational calculation of ("high performance," "high speed") technical systems and databases with the domain of affective management based around personal experience and social interaction.

Cybernetics passed through several historical phases: The Macy conferences that focused on the new science of cybernetics; catastrophe theory; chaos theory; and complexity theory (Peters, 2009). Increasingly, cybernetics and its associated digital theories has become central in understanding the nature of networks and distributed systems in energy, politics and knowledge and also it is significant in conceptualizing knowledge-based economies. Economics itself as a discipline has come to recognize the importance of understanding feedback systems rather than rational agents acting alone, and pure rationality models of economic behavior are being supplemented by economic theories that use complexity theory to predict and model transactions.

Consider one scenario that might follow from this characterization for the university, first described so boldly and accurately by Jean-Francois Lyotard in the now-classic The Postmodern Condition (orig. 1979) a decade earlier than Robbins and Webster (1988). Lyotard's (1984) critique of capitalist techno-science starts as a history of globalization as the history above all of the ways in which information has become transformed into information, that is, into coded messages within a scientific system of cybernetic transmission and communication that has dissolved epistemic and narrative coherence. In these terms the history of integrated world capitalism (IWC) is a system in which "space annihilates time" in the shift from closed to open systems based on mathematical principles of non-linear and self-organized dynamics. I have used Lyotard's argument in The Postmodern Condition as a basis for an approach from radical political economy to knowledge capitalism that focuses on post-industrialism, in order to put the case that education and knowledge increasing become part of a globally IWC which is structured through emerging global information systems and new media networks (Peters, 2012b; see also Peters, 1996). I also embrace the possibility of "open knowledge production" as an area of intellectual activity driven by an ethic of collaboration as a basis for a reconstituted public sphere. 
Lyotard (1984) combined the analysis of postmodernism with postindustrialism, reviving the sociological theory of (post-)industrialism that can be traced back to the first critiques of industrial political economy around alienated labor (Marx), aesthetics of the arts and crafts movements (Morris, Ruskin), modern technology (Heidegger, 1993) and global ecology, and at the same time projected it into the future, anticipating discourses of the knowledge and creative economies that make higher education and research central "industries" or leading economic sectors. His account of the postmodern condition provided grounds for the critique of the knowledge/ information economy at least in its neoliberal forms in terms of the logic of "performativity."

It should therefore come as no surprise that scholars have claimed that the philosophical roots of French (post-structuralist) theory and the technoscientific foundations of cyberspace are born of one and the same cybernetic matrix that was formulated in the aftermath of the Second World War essentially as an industrial-military project by the likes of Norbert Weiner, Claude Shannon and many others in the series of Macy conferences that focus on understanding language and communication as an informational system (Heims, 1991; Lafontaine, 2007; Peters, 2012b).

\section{Theorizing Cybernetic Capitalism}

"Cybernetic capitalism" is a term I adopted to distinguish a group of theories, or, better, positions, on the left that attempt to theorize the nature of the new capitalisms (Peters, Murphy and Marginson, 2009). These contributions can be grouped as largely sociological and left-leaning to characterize them in terms of what they share with and differ from the Marxist theory of industrial capitalism. Late, post and neo capitalism are earlier terms that prefigure the alleged end of capitalism or its radical transformation from its industrial basis in the post-war period. Late capitalism was first used by Sombart in the early twentieth century and Schumpeter, Samuelson and Adorno also used the term. Most famously, Mandel (1975) theorized that late capitalism, as the third stage of multinational capitalism that, far from representing postindustrial economy, is used to describe a universal industrialization. Jameson (1991) uses Mandel's characterization in Postmodernism, or the Cultural Logic of Late Capitalism to describe the emergence of a cultural dominant, or mode of cultural production.

Cybernetic capitalism is a system that has been shaped by the combined forces of formalization, mathematization and aesetheticization beginning in the early twentieth century and associated with developments in mathematical theory, logic, physics, biology and information theory. Its new forms now exhibit themselves as finance capitalism, informationalism, knowledge 
capitalism and the learning economy with incipient nodal developments associated with the creative and open knowledge (and science) economies. The critical question in the wake of the collapse of the global finance system and the impending eco-crisis, concerns whether capitalism can promote forms of social, ecological and economic sustainability.

The new overlapping forms of cybernetic capitalism can be mapped accordingly to five main categories: informational capitalism; cultural capitalism; cognitive capitalism; finance capitalism and biocapitalism. There are strong overlaps and conceptual connections among these five broad categories and also some interesting differences within them. As previously mentioned these five categories are systematically related phenomena that grow out of the same forces of increasing formalization, mathematicization and aestheticization that have been in operation since the beginning of the twentieth century but that began to coalesce and impact after WWII with the development of cybernetics and a group of theories that developed to explain linear and nonlinear dynamical systems (catastrophe, chaos, complexity). These relationships and particularly the way in which they profile education are to be the subject of other papers. It is a grounded analysis that grows out of a typology based on the literature.

One of the major differences with the relation between the university and the industrial economy is that the integration of specific types of technologies in production processes provides a more pervasive set of techniques and a new logic that goes beyond the realm of economics to create new forms of social structural organization and patterns of institutional transformation through high-networks. One of the basic characteristics of contemporary globalization is the significant acceleration of interactions enabled by technology. Technologies of information and communication are shaping reality and reconfiguring world connectedness with a concentration of traffic taking place between certain geographical nodes over others. Technologies of information and communication have led to the material integration of social spaces at a global scale and encouraged transnational strategies of integration, especially where corporations become transnational and finance activity becomes global.

Cybernetic capitalism not only provides and transforms academic, administrative, research and library systems through scalability, enhanced interactivity, personalization and the management of flexibility, it also hollows out university systems, tying the university into a new set of electronic circuits based on mathematics algorithms that are themselves the basis of joint university-info-utility research partnerships that develop matching and parallel information processes serving financial and knowledge markets, high-frequency trading and the development of complex derivatives. In this parallel environment, global information capital exploits creativity, cognitive 
and communicative ability, and taps into the intellectual commons. In an era of communicative capitalism, communication and communicative acts become a commodity to be electronically exchanged at speeds now approaching laser impulses. Algorithmic capitalism (Peters, 2013) now mediates our relationship with data, digital devices and with each other. The pervasiveness of computational techniques becomes increasingly co-extensive with processes of knowledge production, consumption and distribution especially in an age increasingly dependent on "big data" and learning analytics.

Oili-Helena Ylijoki (2013) has documented the way in which universities have become key players in national innovation systems where competitiveness depends on the speed with which scientific knowledge can be commercialized and turned into new products and processes sold in the global marketplace. Universities have been encouraged to become more entrepreneurial in order to supplement declining state revenues. Ylijoki (2013: 243) argues "the transformations in the institutional context and internal functioning of higher education have profound temporal consequences, in particular the speeding up of time." The acceleration of time in late capitalism has led to "the speeding up of the tempo and rhythm in research work in academia," and based on forty in-depth interviews with Finnish academics Ylijoki explores "the impact of the temporal acceleration on how academics perceive their work and its connection to the private sphere of life" (p. 242).

The emphasis has fallen on speeding up the innovation cycle through competitive funding regimes and national research evaluation exercises aimed at the acceleration of the research process from its early design stage through to patent, publication and commercialization. The internet together with new platforms and architectures has promoted smart online journals and full text search and retrieval. The acceleration of academic research is accompanied by new forms of research management that are designed to increase the speed of knowledge generation, commercialization and innovation. Neoliberal managerialism creates a line management system designed to force research throughput with an accent on applications for external funding. Ylijoki (2013: 253) also discusses boundary issues between work time and private time that impinges on "the moral grounding and basic meaning of academic work and the university as an institution."

Algorithmic capitalism, now dominating global financial markets through algorithmic trading, is a cybernetic-based aspect of informational capitalism that has a third phase system development passing beyond simple industrialism, links the spectacular growth of the multinational info-utilities (e.g. Google, Microsoft, Amazon) with the future developments in biocapitalism and the informatization of biology. Financialization is also both a condition of these developments and a consequence (Peters, 2013; Peters and Bulut, 2011). 
The language of the new social media is easily programmable given its algorithmic character, and its numerical coding allows for the automation of many of its functions including media creation. New media are variable and interactive and no longer tied to technologies of exact reproduction such as copying. They are part of a wider new technological paradigm and mode of development characterized by information generation, processing and transmission that have become the fundamental sources of productivity, value and power. We now live in a socially networked universe in which the material conditions for the formation, circulation and utilization of knowledge and learning are rapidly changing from an industrial to information- and mediabased economy.

Siva Vaidhyanathan (2009) begins "The Googlization of Universities" with the following remark:

The relationship between Google and the world's universities is more than close. It is uncomfortably familial. Google has moved to establish, embellish, or replace many core university services such as library databases, search interfaces, and e-mail servers. Its server space and computing power opened up new avenues for academic research. Google Scholar has allowed nonscholars to discover academic research. Google Book Search radically transformed the vision and daily practices of university libraries. Through its voracious efforts to include more of everything under its brand, Google fostered a more seamless, democratized, global, cosmopolitan information ecosystem. But it also contributed to the commercialization of higher education and the erosion of standards of information quality.

He documents the Googlization of students, of scholarship, of book learning and of research to argue that universities must reverse the terms of the relationship to impose their values. Vaidhyanathan (2011) challenges the neoliberal presumption that market forces can best solve problems and suggests:

It had its roots in two prominent ideologies: techno-fundamentalism, an optimistic belief in the power of technology to solve problems ... and market fundamentalism, the notion that most problems are better (at least more efficiently) solved by the actions of private parties rather than by state oversight or investment.

Vaidhyanathan's argument here is one ultimately against neoliberalism in relation to global public knowledge goods, but the theory of cognitive capitalism provides us with a "stage" theory of the changing nature of capitalism, that helps us better to understand the logic of knowledge capitalism that operates on the basis of algorithmic logic to expand a universe of information accessibility while changing the nature of the regime of accumulation. 
The staggering growth of the finance industry sometimes referred to as "financialization" represents a set of overlapping processes that refer not only to the rapid expansion of the financial sector of the capitalist system to the growth of financial institutions of all kinds - but also to a qualitative change in the mode of production, where banking systems jettison traditional banking practices to become commercial investors and multinational corporations develop as financial institutions able to invest and trade directly in financial markets.

Richard Peet (2011) writing for Monthly Review puts it succinctly:

Over the last thirty years, capital has abstracted upwards, from production to finance; its sphere of operations has expanded outwards, to every nook and cranny of the globe; the speed of its movement has increased, to milliseconds; and its control has extended to include 'everything.'

Algorithmic trading is sometimes seen as an explanation of market volatility, especially when risk is not transparent or able to be effectively tracked and monitored. Automated buy-sell programs now account for over 80 percent of all US equity trading. Increasingly, global information systems that operate at the speed of light are now harnessed by HFT (high-frequency trading) firms to create Automated Trading Desks that are capable of trading hundreds of millions of shares daily. So-called "quant trading," after "quantitative trading programs," is now designed by mathematicians and underlies HFT, where stocks are held often for only microseconds.

Financialization is a systematic transformation of capitalism based on the massive expansion of the financial sector, where finance companies have taken over from banks as major financial institutions and banks have moved away from old lending practices to operate directly in capital markets. Large previously non-financial multinational corporations have acquired new financial capacities to operate and gain leverage in financial markets. Universities, students and domestic households have become players in financial markets (the ascendancy of shareholder capitalism) taking on debt and managing assets. In general, financialization represents the dominance of financial markets over declining production by the traditional industrial economy, and a corresponding abstraction of "fictionalized" capital that increasingly controls price mechanisms but adds little or nothing to real value.

To return to Virilio's remark that the old left approach of demanding yet more social justice is just not going to get us very far. If we accept that the financial crisis and increasing financialization is an expression of the exhaustion of the neoliberal model of capitalist development, that its continuing abstraction and increasing speed are ultimately unstable, untraceable and unable to be properly regulated, and that its perpetual expansion, while not 
anchored in anything productively real, nonetheless controls the price mechanism and leads to extensive global inequalities, then how long can it last and where are its suitable substitutes? Financialization characterizes the politics of late neoliberal capitalism allowing it to extract value from the commons: to raid social security and Medicare, to privatize higher education and its infrastructure, to monetize medicine and medical insurance, to massively mortgage student debt, to confiscate depositors' funds, to asset-strip state enterprises. These are all forms of enclosure that permit a tiny but powerful minority to plunder the commonwealth and to capture and harness national systems of knowledge generation, innovation and creativity in the service of the emerging info-financial circuits of global capital (Peters, 2013). This is the set of global processes encouraging the fast capitalism of higher education in an era of cybernetic capitalism.

\section{Acknowledgments}

A version of this paper was previously published as Peters, M. A. (2015), "The University in the Epoch of Digital Reason: Fast Knowledge in the Circuits of Cybernetic Capitalism," in Paul Gibbs, Oili-Helena Ylijoki, Carolina Guzmán-Valenzuela, and Ronald Barnett (eds.), Universities in the Time of Flux: An Exploration of Time and Temporality in University Life. London: Routledge, 9-31.

\section{NOTES}

1. Original article Paul Virilio (2009), "Le krach actuel représente l'accident intégral par excellence," in Le Monde at www.lemonde.fr/idees/article/2009/02/27/ le-krach-actuelrepresente-1-accident-integral-par-excellence_1108473_3232.html

2. See my "Speed, Power and the Physics of Finance Capitalism" on which the first part of this paper is based, www.truth-out.org/news/item/16960-speed-powerand-thephysics-of-finance-capitalism. Virilio says: "it is impossible to understand what is going on if one does not implement a (policy based on the) political economy of speed, the speed that technological progress engenders, and if one does not link (this policy) to the 'accidental' character of History."

3. It is widely reported that student debt in the US has topped the $\$ 1$ trillion mark with "debts for life" the second largest form of debt after housing mortgages. See www.asa.org/policy/resources/stats/default.aspx

4. See Burris (2013) on "The Algebra of Logic Tradition;" O'Regan (2008) on the history of computing; and Stankovic and Astola (2011) on switching theory.

5. See www.fastcapitalism.com/. I was invited to sit on the editorial board when it was founded but I have not yet contributed to the journal.

6. See www.slideshare.net/mpt001/theatre-of-fast-knowledge-pp

7. This account of cybernetics is taken from Peters (2012a).

8. Tiqqun is the title of a French periodical developed by a collective strongly influenced by Agamben's work. The Cybernetic Hypothesis' is available at https:// 
cybernet.jottit.com/ The work also bears the imprint of Deleuze's "Postscript on Societies of Control" at https://files.nyu.edu/dnm232/public/deleuze_postcript.pdf

9. See http://en.wikipedia.org/wiki/List_of_the_largest_information_technology_ companies; http://en.wikipedia.org/wiki/List_of_largest_Internet_companies and http://im.ftstatic.com/content/images/a81f853e-ca80-11e1-89f8-00144feabdc0.pdf

\section{REFERENCES}

Agger, B., and Luke, T. (2013a), "Getting to Ten," www.fastcapitalism.com/

Agger, B., and Luke, T. (2013b), "All That is Solid: Writing, Reading and Publishing in Postmodern Capitalism," triple C 11(2): 575-580. www.triple-c.at

Ashby, W. R. (1956), An Introduction to Cybernetics. London: Chapman and Hall.

Babe, R. (2006), "The Political Economy of Knowledge: Neglecting Political Economy in the Age of Fast Capitalism (as Before)," www.uta.edu/huma/agger/ fastcapitalism/2_1/babe.html

Besley, T., and Peters, M. A. (2006), "The Theatre of Fast Knowledge: Performative Epistemologies in Higher Education," Review of Education, Pedagogy, and Cultural Studies 27(2): 111-126.

Boole, G. (1847), The Mathematical Analysis of Logic, Being an Essay Towards a Calculus of Deductive Reasoning. Originally published Cambridge: Macmillan, Barclay \& Macmillan; reprinted Oxford: Basil Blackwell (1951).

Boulding, K. (1953), "Toward a General Theory of Growth," Canadian Journal of Economics and Political Science 19 (reprinted in General Systems Yearbook, Vol. 1, 1956).

Brin, S., and Page, L. (no date), "The Anatomy of a Large-Scale Hypertextual Web Search Engine," http://infolab.stanford.edu/ backrub/google.html

Burris, S. (2013), "The Algebra of Logic Tradition," in E. N. Zalta (ed.), The Stanford Encyclopedia of Philosophy, Summer 2013 Edition, http://plato.stanford. edu/archives/sum2013/entries/algebra-logic-tradition/

Deleuze, G. (1995), “Control and Becoming," in Negotiations 1972-1990. New York: Columbia University Press.

François, C. (1999), "Systemics and Cybernetics in a Historical Perspective," Systems Research and Behavioral Science 16: 203-219.

Heidegger, M. (1993), “The Question Concerning Technology," in D. Krell (ed.), Basic Writings. New York: HarperCollins.

Heims, S. J. (1991), The Cybernetics Group. Boston, MA: The MIT Press.

Jameson, F. (1991), Postmodernism, or the Cultural Logic of Late Capitalism. Durham, NC: Duke University Press.

Kant, I. (1798/1979), The Conflict of the Faculties. Tr. M. J. Gregor. New York: Abaris Books.

Klinke, I. (2012), "Chronopolitics: A Conceptual Matrix," Progress in Human Geography 37(5): 673-690.

Lafontaine, C. (2007), “The Cybernetic Matrix of 'French Theory,'” Theory, Culture \& Society 24(5): 27-46. http://dx.doi.org/10.1177/0263276407084637

Luke, T. W. (2005), "Scanning Fast Capitalism: Quasipolitan Order and New Social Flowmations," www.uta.edu/huma/agger/fastcapitalism/1_1/luke.html 
Lyotard, J.-F. (1984), The Postmodern Condition: A Report on Knowledge. Tr. G. Bennington and B. Massumi. Minneapolis, MN: University of Minnesota Press.

Mandel, E. (1975), Late Capitalism. London: Humanities Press.

Mandelbrot, B. (1977), Fractal Forms, Change and Dimensions. San Francisco, CA: Freeman.

Miller, J. G. (1978), Living Systems. New York: McGraw-Hill.

O'Regan, G. (2008), A Brief History of Computing. London: Springer.

Pask, G. (1975), The Cybernetics of Human Learning and Performance. London: Hutchinson.

Peet, R. (2011), “Contradictions of Finance Capital,” Monthly Review 63(7). http:// monthlyreview.org/2011/12/01/contradictions-of-finance-capitalism/

Peters, M. A. (1996) (ed.), Education and the Postmodern Condition. Foreword by J-F. Lyotard. Westport, CT. and London: Bergin \& Garvey.

Peters, M. A. (2011), "Critical Historiographies in Educational Theory: Retemporalizing Experience 'After' The Spatial Turn,” Geopolitics, History and International Relations 3(2): 48-67.

Peters, M. A. (2012a), "Cybernetics," in H. K. Anheier and M. Juergensmeyer (eds.), The Encyclopedia of Global Studies. Sage. http://knowledge.sagepub.com/view/ globalstudies/n117.xml

Peters, M. A. (2012b), "Postmodern Educational Capitalism, Global Information Systems and New Media Networks," Policy Futures in Education 10(1): 23-29.

Peters, M. A. (2012c), "Algorithmic Capitalism and Educational Futures: Informationalism and the Googlization of Knowledge," TruthOut. http://truth-out.org/ news/item/8887-algorithmic-capitalism-and-educational-futures-informationalismand-the-googlization-of-knowledge

Peters, M. A. (2013), "Speed, Power and the Physics of Finance Capitalism," TruthOut. www.truth-out.org/news/item/16960-speed-power-and-the-physics-offinance-capitalism

Peters, M. A., and Bulut, E. (eds.) (2011), Cognitive Capitalism, Education and Digital Labor. New York: Peter Lang.

Peters, M. A., Britez, R., and Bulut, E. (2009), "Cybernetic Capitalism, Informationalism and Cognitive Labor," Geopolitics, History, and International Relations 1(2): 11-40.

Peters, M. A., Murphy, P., and Marginson, S. (2009), Creativity and the Global Knowledge Economy. New York: Peter Lang.

Prigogine, I. (1955), Thermodynamics of Irreversible Processes. Springfield, IL: Thomas Press. (His first paper in 1940, with J. M. Wiame in Experimentia 2 much more after 1955 until nowadays.)

Ritzer, G. (1993), The McDonaldization of Society. Thousand Oaks, CA: Pine Forge Press.

Robbins, K., and Webster, F. (1988), "Cybernetic Capitalism: Information, Technology, Everyday Life," in V. Mosko and J. Wasko (eds.), The Political Economy of Information. Madison, WI: The University of Wisconsin Press, 45-75. http://glotta.ntua.gr/IS-Social/CyberCulture/RobinsCybernetic.html.

Shannon, C., and Weaver, W. (1949), The Mathematical Theory of Communication. Urbana, IL: University of Illinois Press. 
Simon, H. A. (1962), The Architecture of Complexity. (Reprinted in General Systems Yearbook, Vol. X, 1965.)

Stankovic, R. S., and Astola, J. (2011), From Boolean Logic to Switching Circuits and Automata: Towards Modern Information Technology. Dordrecht: Springer.

Teeple, G. (1995), Globalization and the Decline of Social Reform. Toronto: Garamond Press.

Tomlinson, J. (2007), The Culture of Speed: The Coming of Immediacy. Thousand Oaks, CA, and London: Sage.

Umpleby, S. (2005), "A History of the Cybernetics Movement in the United States," Journal of the Washington Academy of Sciences 91(2): 54-66.

Vaidhyanathan, S. (2009), "The Googlization of Universities," in The NEA 2009 Almanac of Higher Education, Washington, DC, 65-74.

Vaidhyanathan, S. (2011), The Googlization of Everything (And Why We Should Worry). Berkeley, CA: University of California Press.

Virilio, P. (2008), "Paul Virilio on the Crisis," in Radical Perspectives on the Crisis, https://sites.google.com/site/radicalperspectivesonthecrisis/news/paul-virilio-on thecrisis

von Bertalanffy, L. (1950), "An Outline of General System Theory," British Journal for the Philosophy of Science 1(2): 134-165.

Vostal, F. (2013), “Thematizing Speed: Between Critical Theory and Cultural Analysis," European Journal of Social Theory 17: 95. http://est.sagepub.com/ content/17/1/95

Weiner, N. (1948), Cybernetics or Control and Communication in the Animal and the Machine. Paris: Hermann \& Cie; Cambridge, MA: The Technology Press; New York: John Wiley \& Sons Inc.

Ylijoki, O.-H. (2013), "Boundary-work Between Work and Life in the High-speed University," Studies in Higher Education 38(2): 242-255.

Zadeh, L. (1965), "Fuzzy Sets," Information and Control 8: 338-353. 